\title{
Pengembangan Konten Nilai-Nilai Kecerdasan Emosional dalam Materi Pembelajaran Fisika pada Bahan Ajar
}

\author{
Zulhendri Kamus ${ }^{1)}$, Asrizal ${ }^{1)}$, Aufha Diny Putri ${ }^{1)}$ \\ ${ }^{1)}$ Jurusan Fisika, FMIPA Universitas Negeri Padang \\ zul_fi@fmipa.unp.ac.id
}

\begin{abstract}
Learning of physics according to the curriculum 2013 emphasizes the comprehensive achievement of student competence, so that the equality between soft skills and hard skills is formed. The role of learning materials especially physics subject is very important to support implementation of curriculum for physics learning. In fact, the knowledge and skills content of physics learning materials used students in school is more than attitude content. Development of physics learning materials integrated the values of emotional intelligence is the alternative solution of this problem. This research use Research and Development $(R \& D)$ method. This paper explains results of preliminary and main field testing of the physics learning materials integrated the values of emotional intelligence. This product has a validity value of around 85.83 or a very valid category. Based on data analysis, there are two results from this research. First, the practicality value of product according to teacher and student are an average score of 88.1 and 82 respectively or very high category. Second, the physics learning materials integrated emotional intelligence values is effective to improve the student competences in learning. The results of research indicate that the emotional intelligence value developed in physics material is feasible using in physics learning than it able to realize the comprehensive competence achievement.
\end{abstract}

Keywords : emotional intelligence, physics, learning material, competence

This is an open access article distributed under the Creative Commons 4.0 Attribution License, which permits unrestricted use, distribution, and reproduction in any medium, provided the original work is properly cited. $\odot 2018$ by author and Universitas Negeri Padang.

\section{PENDAHULUAN}

Kemampuan berpikir seseorang yang disebut kecerdasan dapat membantu seseorang untuk mengarahkan tindakan yang ingin dilakukan dan menyelesaikan masalah yang dihadapi dalam kehidupan (Gardner, 1993). Kecerdasan dari seseorang juga dapat membantu nya untuk bertahan hidup dengan berbagai persoalan yang dihadapi di dunia ini. Selanjut nya, kecerdasan juga penting dimiliki dalam dunia pendidikan untuk membentuk karakter peserta didik. Karena itu, penumbuhan ke cerdasan peserta didik melalui pembelajaran di sekolah sesuai dengan ciri Pendidikan abad 21 (Kemendikbud, 2017).

Pendidikan bertujuan untuk mencerdas kan segenap insan atau peserta didik. Pendidikan merupakan proses yang dilalui oleh seseorang dengan cara-cara tertentu dalam memperoleh pengetahuan, pemahaman, dan bertingkah laku sesuai kodratnya. Pendidikan berpengaruh juga untuk pengembangan kemampuan yang dimiliki seseorang. Pendidikan mempunyai perananamat pentinguntuk kemajuan suatu bangsa dan negara. Di Indonesia, pendidikan diselenggara kan untuk mewujudkan rumusan tujuan pen didikan nasional yang tertuang dalam Undang-Undang No. 20 Tahun 2003 yaitu untuk me ngembangkan kemampuan yang dimiliki peserta didik untuk menjadi individu sebagai warga negara yang demokratis, berkeyakinan dan beradap. Berbagai upaya dilakukan untuk me wujudkan tujuan pendidikan yang bermutu.

Pihak pemerintah berupaya untuk me ningkatkan mutu pendidikan melalui berbagai cara anara lain pembenahan berbagai sarana dan prasarana pendidikan (perpustakaan, gedung, laboratorium dan sebagainya), program serti fikasi terhadap guru dan merevisi kurikulum yang digunakan satuan pendidikansaat ini yaitu kurikulum 2013.

Implementasi kurikulum 2013 bertujuan untuk mewujudkan pencapaian kompetensi sikap, keterampilan, dan pengetahuan secara utuh. Selain itu, kurikulum 2013 lebih ditekan kan pada penguatan pendidikan karakter dari seorang peserta didik agar terbentuk akhlak mulia dan budi pekerti. Penerapan kurikulum 2013 pada setiap satuan pendidikan bertujuan agar 
peserta didik mampu meningkatkan pengetahuan, membangun nilai-nilai karakter dan akhlak mulia dalam dalam diri untuk mampu bersikap dan berperilaku baik dalam kehidupan sehari-hari. Karena itu, kurikulum 2013 dikembangkan agar peserta didik memiliki karakter dan kompetensi yang utuhatau kompre hensif (Kaimuddin, 2014).

Rumusan kompetensi dalam kurikulum 2013 terdiri dari kompetensi inti dan kompetensi dasar. Ada empat kompetensi inti yang terdapat dalam kurikulum 2013 yaitu kompetensi sikap spiritual, sikap sosial, pengetahuan dan ke terampilan. Semua kompetensi inti dijabarkan menjadi kompetensi dasar yang akan dicapai peserta didik melalui pembelajaran. Ruang lingkup dari materi pembelajaran yang perlu dikuasai oleh peserta didik didasarkan pada kompetensi dasar dari setiap mata pelajaran yang termaktub dalam Permendikbud nomor 24 tahun 2016.

Tujuan pendidikan yang tertuang dalam kurikulum mengembangkan kompetensi peserta didik secara holistik baik dari perspektif agama hingga psikologi. Musfah (2012) mengungkap kan bahwa ada beberapa istilah pengembangan kompetensi manusia, salah satunya dalam perspektif psikologi disebut kecerdasan yang terdiri dari kecerdasan intelektual, social, emosional dan spiritual. Menurut konsep psikologi yang dikemukakan oleh Uno (2006), kecerdasan emosional merupakan kemampuan dalam mengendalikan emosi dan pengambilan keputusan atau tindakan yang tepat. Kecerdasan emosional dapat mendorong seseorang mencari manfaat dan mengubah sesuatu yang dipikirkan menjadi yang dijalani. Kecerdasan emosional menuntut seseorang untuk mempercayai diri sendiri dan orang lain, mengelola emosi dalam kehidupan sehari-hari.

Kecerdasan emosional penting dibangun dalam diri seseorang terutama peserta didik. Kecerdasan emosional dapat dikembangkan dengan kemauan, kesungguhan, dan pelatihan. Pada berbagai pernyelesaian permasalahan yang dihadapi dalam kehiduoan sehari-hari, kecerdas an intelektual (IQ) hanya menyumbang paling tinggi 20 persen untuk penentuan sukses hidup, 80 persen didapatkan oleh kemampuan-ke mampuan lain salah satunya adalah kecerdasan emosional (Goleman, 1999). Kecerdasan emosi onal juga penting untuk dimiliki seseorang agar mampu menggunakan kemampuan-kemampuan kognitif secara maksimal. Selain itu, kecerdasan emosional dapat meningkatkan potensi diri dari seseorang untuk mempelajari keterampilanketerampilan praktis (Masaong, 2011)

Goleman (1999) mengemukakan lima indikator dari kecerdasan emosional yaitu kesadaran diri, pengaturan diri, motivasi, empati dan keterampilan sosial. Melalui kecerdasan emosional, peserta didik akan mampu mengenal, mengendalikan dan memotivasi diri sendiri serta berempati dan memiliki kemampuan bersosial isasi dengan lingkungan sekitar. Pembelajaran yang dialami oleh peserta didik untuk mem bangun kecerdasan emosional akan mampu melahirkan individu peserta didik yang ber karakter.

Peserta didik tidak hanya terpaku untuk penguasaan ilmu pengetahuan dari mata pelajar an melalui proses pembelajaran. Aspek ke terampilan dan sikap juga harus dikuasai oleh peserta didik. Pada aspek sikap inilah peserta didik diharapkan mampu menanamkan motivasi dirinya sendiri menjadi pribadi yang mulia berdasarkan ilmu pengetahuan yang dipelajari nya dalam proses pembelajaran. Sikap ter banngun sebagai hasil dari pengetahuan yang didapat oleh peserta didik itu sendiri. Sikap mencerminkan pemahaman dari seorang peserta didik terhadap pengetahuan yang diperolehnya melalui aktivitas belajar. Proses pembelajaran harus diarahkan pada pencapaian kompetensi sikap, pengetahuan dan keterampilan secara komprehensif. Karena itu, peningkatan kom petensi pengetahuan dan keterampilan diharap kan berdampak terhadap terbentuknya kom petensi sikap yang semakin baik.

Pada mata pelajaran fisika, peserta didik dapat mengembangkan kecerdasan emosional melalui pemahaman terhadap materi Fisika. Peserta didik mengetahui bahwa gerak me lingkar merupakan gerakan suatu benda dalam lintasan melingkar. Balap sepeda pada lintasan stadion berbentuk lingkaran adalah salah satu contoh benda yang bergerak melingkar. Per cepatan sentripental akan dialami oleh sepeda yang melaju di lintasan melingkar. Melalui proses pembelajaran, peserta didik mengetahui bahwa sepeda dengan kelajuan yang tinggi akan mengalami gaya sentripental yang tinggi juga. Sepeda akan terlempar ke luar lintasan apabila kelajuan yang dialami melebihi kelajuan maksimum yang diizinkan. Pengetahuan tentang konsep percepatan sentripetal pada gerak melingkar ini dapat membangun ke cerdasan emosional dari peserta didik yakni tumbuh sikap 
hati-hati. Peserta didik saat menonton pertunjuk an balap sepeda dalam lintasan melingkar akan cerdas secara emosional yakni berusaha me nonton tidak dekat dengan pinggir lintasan. Apabila ada kecelakaan maka sepeda akan terlempar ke luar lintasan dan dapat mengenai penonton yang di pinggir lintasan. Sikap hati-hati tersebut dapat muncul dari pengetahuan Fisika peserta didik pada pem belajaran Fisika di sekolah.

Keberadaan dari bahan ajar menjadi penting untuk mendukung pencapaian dari tujuan pembelajaran. Bahan ajar sebagai salah satu sumber belajar yang harus dimiliki oleh peserta didik akan berdampak terhadap pencapaian hasil belajar. Bahan ajar yang digunakan dalam pembelajaran hendaknya sesuai dengan kebutuhan peserta didik. Bagi guru, bahan ajar menjadi pedoman untuk mengarahkan pembelajaran yang akan dialami oleh peserta didik. Penggunaan bahan ajar dapat juga memudahkan guru dalam melakukan kegiatan pembelajaran dan membantu peserta didik dalam belajar. Penggunaan bahan ajar dalam proses pembelajaran diharapkan dapat membantu tercapainya kompetensi secara utuh.

Buku fisika sebagai salah satu sumber belajar yang umum digunakan peserta didik di sekolah masih belum memiliki jabaran konten nilai-nilai kecerdasan emosional yang memadai. Analisis terhadap empat buah buku fisika yang tersedia di pasaran dan digunakan oleh peserta didik, konten nilai-nilai kecerdasan emosional yang termuat dalam buku masih berbentuk ajakan atau seruan sebesar 4,07 persen. Nilai-nilai kecerdasan emosional diuraikan dalam buku belum didasarkan kepada konsep-konsep fisika. Isi buku masih didominasi dengan uraian tentang pengetahuan fisika dan keterampilan laboratorium sebesar 89,53 persen. Selain itu, proses pembelajaran yang dialami oleh peserta didik lebih diarahkan pada pembentukan pengetahuan. Hasil pengamatan terhadap proses pembelajaran di kelas, kegiatan yang dilakukan oleh peserta didik dalam bentuk duduk, mendengar, mencatat, berdiskusi, mengerjakan tugas secara mandiri dan kelompok, tanya-jawab, mengamati demontrasi atau alat peraga dan lainlain. Semua kegiatan ini bertujuan agar siswa memiliki kompetensi pengetahuan tentang fisika. Penanaman nilai-nilai emosional kepada peserta didik masih dalam bentuk himbauan dan sedikit dilakukan. Karena itu, pengem bangan konten nilai-nilai kecerdasan emosional dalam bahan ajar fisika penting dilakukan.

Pada penelitian sebelumnya telah dilaku kan pengembangan bahan ajar bermuatan nilainilai kecerdasan komprehensif. Kamus (2015) telah mengembangkan nilai-nilai social dalam materi fisika kelas $\mathrm{X}$ SMA. Produk yang dihasilkan dalam penelitian tersebut adalah bahan ajar bermuatan kecerdasan komprehensif yang memiliki validitas sangat tinggi. Pada tahun berikutnya, Kamus dan Asrizal (2016) melakukan implementasi buku teks fisika bermuatan kecerdasan komprehensif pada pembelajaran peserta didikkelas XSMA Kota Padang menggunakan pendekatan saintifik. Hasil dari penelitian ini adalah terdapat peningkatan terhadap pencapaian kompetensi sikap, pengetahuan, dan keterampilan peserta didik. Syam (2017) menerapkan model pem belajaran berbasis masalah untuk melihat pengaruh buku ajar bermuatan kecerdasan komprehensif terhadap pencapaian kompetensi. Hasil dari penelitian menunjukkan bahwa penerapan buku ajar bermuatan kecerdasan komprehensif mampu meningkatkan hasil belajar fisika peserta didik baik dari aspek pengetahuan, sikap spiritual, sikap sosial, dan keterampilan.

Hasil dari berbagai penelitian yang telah dilakukan sebelumnya menunjukkan bahwa pengembangan bahan ajar bermuatan kecerdas an komprehensif valid, praktis, efektif dan memberikan dampak terhadap peningkatan pencapaian kompetensi peserta didik secara utuh. Kecerdasan komprehensif yang dikembang kan terdiri dari kecerdasan intelektual, kinestetik, spiritual, social dan emosional. Nilai kecerdasan yang dikembangkan dari pengetahu an fisika masih terbatas, salah satunya ke cerdasan emosional. Oleh karena itu perlu dilakukan penelitian lanjutan untuk yang di khususkan padapengembangan konten kecerdas an emosional pada materi fisika. Tujuan dari penelitian adalah mengetahui validitas, praktikal itas dan efektivitas dari konten nilai-nilai ke cerdasan emosional dari materi fisika dalam bahan ajar.

\section{METODE PENELITIAN}

Jenis penelitian yang digunakan adalah penelitian dan pengembangan $(R \& D)$. Menurut Sugiyono (2008), metode penelitian dan pengembangan $(R \& D)$ adalah metode penelitian yang digunakan untuk menghasilkan produk tertentu dan menguji keefektifan produk tersebut. 
Produk yang dihasilkan adalah bahan ajar fisika dengan konten nilai-nilai kecerdasan emosional.

Pada penelitian ini terdapat variabel bebas dan variabel terikat. Variabel bebas pada penelitian ini adalah bahan ajar fisika dengan konten nilai-nilai kecerdasan emosional. Variabel terikat pada penelitian ini adalah kompetensi pengetahuan dan sikap peserta didik. Peneliti melakukan uji lapangan awal untuk melihat praktikalitas dan uji lapangan utama untuk mengetahui efektivitas dari bahan ajar hasil revisi dari uji lapangan awal.

Data primer adalah data yang diperoleh langsung oleh peneliti. Data primer dari penelitian ini adalah hasil analisis buku sumber fisika, hasil observasi proses proses pembelajar an fisika, hasil validasi bahan ajar fisika dengan konten nilai-nilai kecerdasan emosional, hasil praktikalitas penggunaan bahan ajar fisika dengan konten nilai-nilai kecerdasan emosional, serta hasil efektivitas penggunaan bahan ajar fisika dengan konten nilai-nilai kecerdasan emosional. Data sekunder dari penelitian ini adalah nilai Ujian Tengah Semester 1 kelas X SMA Negeri 4 Padang. Hasil analisis terhadap nilai Ujian Tengah Semester 1 menunjukkan bahwa pencapaian kompetensi pengetahuan siswa masih tergolong rendah.

Subjek penelitian ini adalah konten nilainilai kecerdasan emosional yang dikembangkan dalam materi fisika pada bahan ajar. Responden pada penelitian ini terdiri dari dosen jurusan Fisika FMIPA UNP, guru, dan peserta didik kelas $\mathrm{X}$ SMAN 4 Padang. Dosen jurusan Fisika FMIPA UNP sebagai validator. Guru Fisika SMA Negeri 4 Padang sebagai praktisi. Objek penelitian ini adalah bahan ajar fisika dengan konten nilai-nilai kecerdasan emosional. Sugi yono (2016) mengemukakan ada tiga belas langkah yang dilakukan dalam penelitian dan pengembangan. Pada penelitian ini dilakukan langkah-langkah yaitu penelitian terhadap produk yang telah ada, studi literatur, perencana an pengembangan produk, penngujian internal desain, revisi desain, pembuatan produk, uji lapangan awal, revisi produk dan uji lapangan utama produk.

Studi literatur dilakukan untuk mendapat kan informasi untuk perancangan produk tertentu yang diharapkan bisa memecahkan masalah dalam penelitian yang dilakukan. Ada tiga informasi yang didapat dari studi literatur yang dilakukan. Informasi pertama adalah informasi mengenai penerapan nilai kecerdasan emosional dalam pembelajaran fisika. Instrumen yang digunakan adalah lembar observasi ter hadap proses pembelajaran. Hasilnya menunjuk kan bahwa penerapan nilai kecerdasan emosi onal berdasarkan konsep-konsep fisika masih rendah. Informasi kedua adalah informasi me ngenai nilai kecerdasan emosional dalam bahan ajar. Instrumen yang digunakan ialah lembar penilaian terhadap buku peserta didik. Hasil analisis data menunjukkan buku sumber yang digunakan di sekolah belum memiliki konten nilai-nilai kecerdasan emosional yang dikaitkan dengan konsep-konsep fisika. Informasi ketiga adalah hasil belajar peserta didik.

Bahan ajar dengan konten nilai-nilai kecerdasan emosional ini memiliki halaman depan (cover), petunjuk belajar, kompetensi yang akan dicapai, peta konsep, isi materi pembelajaran, contoh soal, konten nilai-nilai kecerdasan emosional, informasi pendukung, latihan-latihan, lembar kerja, evaluasi, dan respon terhadap hasil evaluasi.

Pengujian internal desain dilakukan untuk mengetahui validitas dari perencanaan desain produk. Sedangkan uji lapangan awal dilakukan untuk mengetahui kepraktisan bahan ajar dengan konten nilai-nilaikecerdasan emosional oleh guru dan peserta didik. Komponen penilaian untuk uji praktikalitas yaitu kemudahan peng gunaan, manfaat, kemenarikan, dan kejelasan. Praktikalitas bahan ajar diuji menggunakan lembar praktikalitas produk. Setelah itu didapat kan bobot nilai.

Pembobotan nilai dilakukan berdasarkan skala Likert. Skala Likert dapat digunakan untuk menilai sikap, gagasan dan pemahaman se seorang mengenai gejala social. Jawaban setiap pertanyaan pada lembar validitas dan praktikal itas memiliki rincian skor, yaitu: skor 4 untuk jawaban sangat setuju, skor 3 untuk jawaban setuju, skor 2 untuk jawaban tidak setuju, dan skor 1 untuk jawaban sangat tidak setuju. Teknik pengumpulan data validitas dan praktikal itas dengan cara memberikan lembaranvaliditas pada tenaga ahli dan lembaran praktikalitas bahan ajar kepada guru dan peserta didik. Nilai bobot dihitung dengan menjumlahkan seluruh nilai bobot dan dibagi dengan bobot maksimum, kemudian dikalikan 100 seperti persamaan berikut.

$$
\text { nilai }=\frac{\text { bobot total }}{\text { bobot maksimum }} \times 100(1)
$$


Bobot total adalah total skor yang diperoleh masing-masing komponen penilaian, kriteria validitas dan praktikalitas dapat ditentu kan berdasarkan nilai yang diperoleh. Kriteria validitas dan praktikalitas dapat ditentukan ber dasarkan nilai yang diperoleh.

Penilaian praktikalitas produk ditentukan berdasarkan kriteria interpretasi skor yang diperoleh. Klasifikasi nilai kepraktisan yang digunakan pada penelitian ini adalah pada rentangan nilai 61-100. Data uji validitas dan uji kepraktikalitas pada penelitian ini dianalisis memakai analisis statistik deskriptif. Statistik deskriptif adalah statistik yang digunakan untuk menganalisis data dengan cara mendeskripsikan data sebagaimana adanya tanpa bermaksud membuat kesimpulan yang berlaku untuk umum.

Uji lapangan utama dilakukan untuk mengetahui efektivitas produk melalui ekspe rimen untuk membandingkan keadaan sebelum dan sesudah penggunaan produk dalam pem belajaran. Desain eksperimen ini dapat dilihat pada Gambar 1.

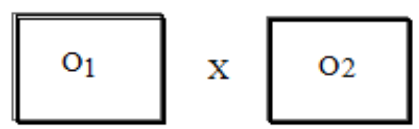

Gambar 1. Desain Eksperimen.

Simbol $\mathrm{O}_{1}$ adalah nilai sebelum diberikan bahan ajar fisika dengan konten nilai-nilai kecerdasan emosional. Simbol $\mathrm{O}_{2}$ adalah nilai sesudah penggunaan bahan ajar fisika dengan konten nilai-nilai kecerdasan emosional. Efektivitas diukur dengan cara membandingkan antara nilai $\mathrm{O}_{2}$ dengan $\mathrm{O}_{1}$. Jika nilai $\mathrm{O}_{2}$ lebih besar dari nilai $\mathrm{O}_{1}$, maka dapat dikatakan perlakuan tersebut efektif. Uji coba produk dilakukan di SMA Negeri 4 Padang kelas X MIA 6.

Lembar uji lapangan utama diberikan dalam bentuk lembar tes hasil belajar dan lembar penilaian diri. Lembar hasil belajar ini berupa pretes dan pos tes. Pretes diberikan sebelum diberikan perlakuan dan postes diberikan kepada peserta didik setelah diberikan perlakuan. Perlakuan yang dimaksud adalah menggunakan bahan ajar dengan konten nilai-nilai kecerdasan emosional dalam pembelajaran fisika. Jika terdapat peningkatan hasil belajar siswa maka bahan ajar tersebut dapat dikatakan efektif. Penilaian sikap dilakukan dengan memberikan lembar penilaian sikap kepada peserta didik sebelum dan sesudah penggunaan bahan ajar dengan konten nilai-nilaikecerdasan emosional. Komponen sikap yang dinilai adalah kesadaran diri, pengaturan diri, motivasi, empati, dan keterampilan sosial.

Analisis efektivitas produk dilakukan setelah peserta didik diberikan perlakuan. Per lakuannya adalah penggunaan bahan ajar dengan konten nilai-nilaikecerdasan emosional dalam proses pembelajaran fisika. Berdasarkan hasil analisis akan diketahui seberapa tingkat keefektivan produk yang dihasilkan. Analisis keefektifan produk dilakukan melalui nilai signifikansi perbedaan hasil sistem kerja lama dengan sistem kerja baru tersebut menggunakan uji t berkorelasi dengan rumus yang digunakan.

$$
t=\frac{\overline{X_{1}}-\overline{X_{2}}}{\sqrt{\frac{s_{1}^{2}}{n_{1}}+\frac{s_{2}^{2}}{n_{2}}-2 r\left(\frac{s_{1}}{\sqrt{n_{1}}}\right)\left(\frac{s_{2}}{\sqrt{n_{2}}}\right)}}(2)
$$

$\mathrm{X}_{1}=$ Rata-rata nilai pretes

$\mathrm{X}_{2}=$ Rata-rata nilai postes

$\mathrm{S}_{1}=$ Simpangan baku pretes

$\mathrm{S}_{2}=$ Simpangan baku poster

$\mathrm{S}_{1}{ }^{2}=$ Varians nilai pretes

$\mathrm{S}_{2}{ }^{2}=$ Varians nilai postes

$\mathrm{r}=$ Korelasi antara data dua kelompok

Nilai $r$ pada persamaan adalah koefisien korelasi nilai pretes dan postes peserta didik. Nilai $r$ dapat dihitung menggunakan rumus korelasi productmoment, dengan rumus:

$$
r_{X Y}=\frac{N(\Sigma X Y)-(\Sigma X)(\Sigma Y)}{\sqrt{N\left(\Sigma X^{2}\right)-(\Sigma X) N \Sigma Y^{2}-\Sigma Y^{2}}}
$$

Keterangan:

$\mathrm{X}=$ Rata-rata nilai pretes

$\mathrm{Y}=$ Rata-rata nilai postes

$\mathrm{r}_{\mathrm{XY}}=$ Koefisien korelasi nilai

Harga $t_{\text {hitung }}$ dapat diperoleh dengan men stubstitusikan nilai $r$ ke persamaan $t_{\text {hitung. }}$. Kemudian harga $t_{\text {hitung }}$ yang diperoleh dibanding kan dengan nilai $t_{\text {tabel }}$ distribusi $t$ dengan besar taraf kesalahan adalah 5\%. Bila harga $t_{\text {hitung }}$ lebih kecil dari $t_{\text {tabel }}$ maka hipotesis kerja diterima. Artinya pembuatan bahan ajar fisika dengan konten nilai-nilai kecerdasan emosional untuk pembelajaran fisika berada pada tingkat yang valid dan efektif digunakan dalam proses pembelajaran.

\section{HASIL DAN PEMBAHASAN}

Hasil dari penelitian ini adalah pengguna an bahan ajar dengan konten nilai-nilai kecerdasan emosional adalah praktis dan efektif dalam pembelajaran fisika. Guru yang melaku kan uji kepraktisan dari bahan ajar dengan konten 
nilai-nilai kecerdasan emosional ber jumlah dua orang. Sedangkan, peserta didik yang melakukan uji kepraktisan dari bahan ajar dengan konten nilai-nilai kecerdasan emosional berjumlah 28 orang. Nilai rata-rata dari keempat komponen penilaian kepraktisan bahan ajar ditampilkan pada Gambar 2.

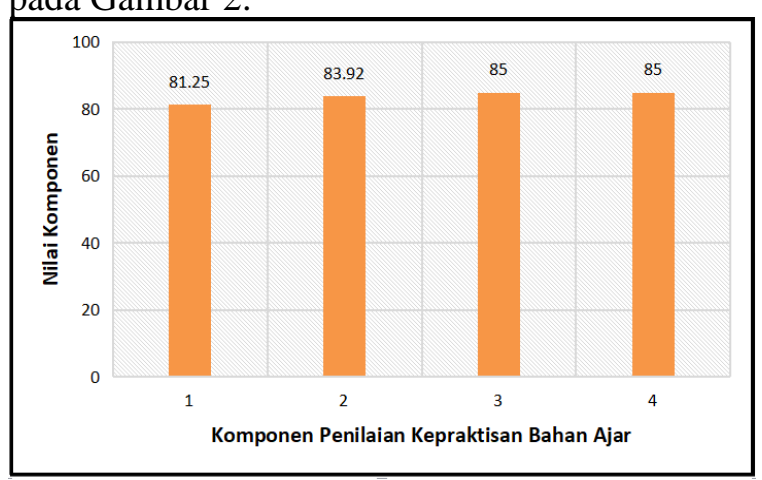

Gambar 2. Nilai Rata-rata Komponen Penilaian Kepraktisan Menurut Guru

Gambar 2 memperlihatkan bahwa nilai rata-rata setiap komponen penilaian kepraktisan dari bahan ajar dengan konten nilai-nilai kecerdasan emosional berkisar antara 81,25 sampai 85,00. Nilai rata-rata dari komponen penilaian kemudahan penggunaan bahan ajar adalah 81,75 dengan kriteria sangat tinggi. Selanjutnya, komponen penilaian manfaat bahan ajar memiliki nilai rata-rata 83,92 dengan kriteria sangat tinggi. Sedangkan nilai rata-rata dari komponen penilaian kemenarikan bahan ajar dan kejelasan dari bahan ajar sama yaitu 85,00 dengan kriteria sangat tinggi.

Uji kepraktisan dari bahan ajar dengan konten nilai-nilaikecerdasan emosional juga dilakukan terhadap peserta didik. Penilaian dilakukan pada empat komponen yang sama. Nilai rata-rata dari setiap komponen penilaian kepraktisan dari bahan ajar menurut peserta didik ditampilkan pada Gambar 3.

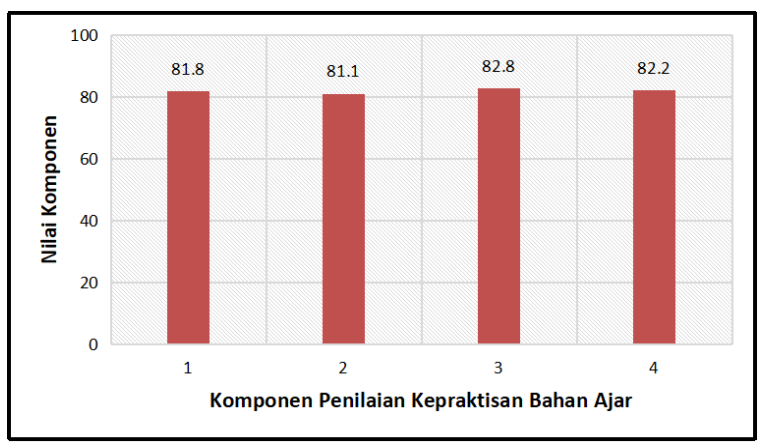

Gambar 3. Nilai Rata-rata Komponen Penilaian Kepraktisan Menurut Peserta Didik
Berdasarkan Gambar 3, nilai rata-rata dari setiap komponen penilaian kepraktisan dari bahan ajar dengan konten nilai-nilai kecerdasan emosional berkisar antara 81,10 sampai 82,80. Komponen penilaian kemudahan penggunaan bahan ajar memiliki nilai rata-rata 81,30 dengan kriteria sangat tinggi. Selanjutnya, nilai rata-rata dari komponen penilaian manfaat bahan ajar yaitu 81,10 dengan kriteria sangat tinggi. Indikator komponen penilaian kemenarikan bahan ajarmemiliki nilai rata-rata 82,80 dengan kriteria sangat tinggi. Nilai dari indikator komponen penilaian kejelasan dari bahan ajar adalah 82,20 dengan kriteria sangat tinggi.

Uji efektivitas dari penggunaan bahan ajar dengan konten nilai-nilai kecerdasan emosional dalam pembelajaran dapat dilihat melalui tes pengetahuan. Hasil tes pengetahuan terhadap peserta didik didapatkan melaluisoal yang diberikan sebelum dan sesudah penggunaan bahan ajar dengan konten nilai-nilai kecerdasan emosional. Penilaian sebelum dan sesudah menggunakan bahan ajar dengan konten nilainilai kecerdasan emosional juga dilakukan terhadap sikap peserta didik. Jumlah dari soal yang disajikan sebanyak 25 butir soal. Hasil sebelum dan sesudahpenggunaan bahan ajar dengan konten nilai-nilai kecerdasan emosional dalam pembelajaran fisika dapat dilihat pada Tabel 1.

Tabel 1. Deskripsi Data Pengetahuan Peserta Didik

\begin{tabular}{|l|l|c|c|}
\hline $\begin{array}{l}\text { N } \\
\text { o }\end{array}$ & $\begin{array}{l}\text { Statistik } \\
\text { Deskriptif }\end{array}$ & Sebelum & Sesudah \\
\hline 1. & Rata-rata & 58,71 & 81,42 \\
\hline 2. & Standar deviasi & 7,30 & 5,57 \\
\hline 3. & Varians & 53,39 & 31,06 \\
\hline 4. & Nilai terendah & 48,00 & 72,00 \\
\hline 5. & Nilai tertinggi & 72,00 & 92,00 \\
\hline 6. & Median & 58,00 & 80,00 \\
\hline 7. & Modus & 60,00 & 80,00 \\
\hline 8. & Rentangan nilai & 24,00 & 20,00 \\
\hline
\end{tabular}

Berdasarkan data yang ditampilkan pada Tabel 1 terlihat bahwa terjadi peningkatan nilai rata-rata dari 58,71 saat sebelum menjadi 81,42 saat sesudah penggunaan bahan ajar. Nilai tertinggi yang diperoleh peserta didik sebelum dan sesudah penggunaan bahan ajarjuga terjadi peningkatan dari nilai 72 menjadi 92 . Gejala yang sama juga ditunjukkan oleh perolehan nilai terendah yang didapatkan oleh peserta didik yakni sebelum penggunaan bahan ajar sebesar 
48,00 meningkat menjadi 72,00 sesudah penggunaan bahan ajar. Pada nilai deviasi terjadi gejala yang baik juga yakni terdapat penurunan dari 7,30 menjadi 5,57 dan nilai varians dari 53,39 menjadi 31,06. Berdasarkan nilai dari seluruh parameter statistik deskriptif, terjadi peningkatan nilai pengetahuan peserta didik setelah menggunakan bahan ajar dengan konten nilai-nilai kecerdasan emosional.

Berdasarkan deskripsi data pengetahuan peserta didik sebelum dan sesudah penggunaan bahan ajardapat dilakukan analisis perbandingan korelasi untuk mengetahui signifikansi perbeda an pengetahuan peserta didik sebelum dan sesudah penggunaan bahan ajar dengan konten nilai-nilai kecerdasan emosional. Dari perhitung an menggunakan persamaan koefisien korelasi product moment diperoleh nilai koefisien korelasi sebesar 0,15 .

Perhitungan dilakukan melalui pengguna an persamaan t-test korelasi. t-hitung didapatkan sebesar $-14,19$. Jumlah dari peserta didik yang mengikuti tes sebanyak 28 orang, maka nilai derajat kebebasannya (dk) yaitu 27, dari hasil $\mathrm{dk}=$ 27 dan harga kritik " $t$ " pada taraf signifikan 5\% diperoleh nilai t-tabel sebesar 1,70.t-hitung yang didapat dari persamaan t-test korelasi bernilai negatif, jadi untuk menguji hipotesis ini dilakukan uji pihak kiri. Harga t-tabel menjadi 1,70 . Berarti t-hitung yang didapatkan lebih kecil dari t-tabel.

Ada perbedaan berarti dari hasil belajar yang diperoleh peserta didik sebelum dan sesudah penggunaan bahan ajar dengan konten nilai-nilai kecerdasan emosional. Perbedaan yang terjadi menunjukkan pengaruh berarti penggunaan bahan ajar sebelum dengan sesudah terhadappencapaian tujuan pembelajaran. De ngan demikian, penggunaan bahan ajar dengan konten nilai-nilai kecerdasan emosional adalah efektif dalam pendekatan saintifik untuk meningkatkan pengetahuan peserta didik.

Penilaian terhadap sikap peserta didik juga dilakukan sebelum dan sesudah mengguna kan bahan ajar dengan konten nilai-nilai kecerdasan emosional. Angket penilaian sikap diberikan untuk bahan ajar yang pernah diguna kan sebelumnya dan untuk bahan ajar dengan konten nilai-nilai kecerdasan emosional. Aspek yang dinilai dari sikap pada kecerdasan emosional yaitu kesadaran diri, pengaturan diri, motivasi, empati dan keterampilan sosial. Peserta didik yang mengisi angket penilaian sikap berjumlah 28 orang. Hasil penilaian terhadap sikap dari peserta didik saat mengguna kan bahan ajar yang pernah digunakan di sekolah dan bahan ajar dengan konten nilai-nilai kecerdasan emosional ditampilkan pada Gambar 4.

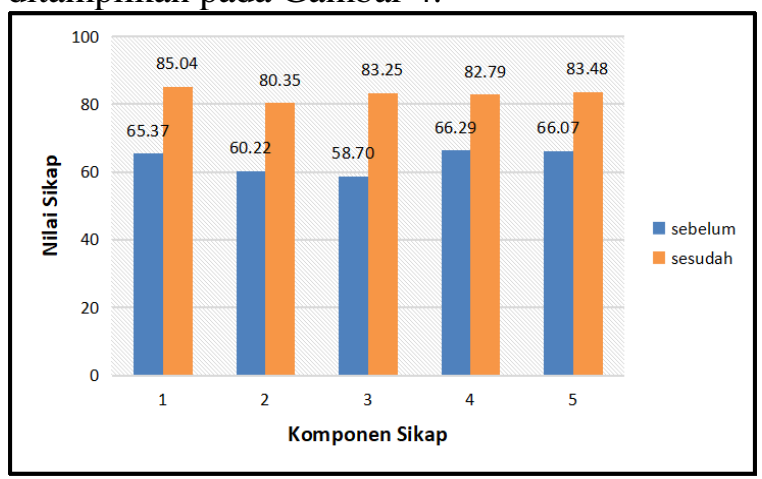

Gambar 4. Hasil Penilaian Sikap Sebelum dan Sesudah Menggunakan Bahan Ajar Fisika

Berdasarkan Gambar 4 dapat dikemuka kan bahwa terjadi peningkatan nilai sikap peserta didik antara sebelum dan sesudah penggunaan bahan ajar dengan konten nilai-nilai kecerdasan emosional. Hasil penilaian sebelum penggunaan bahan ajar dengan konten nilai-nilai kecerdasan emosional berkisar antara 58,70 sampai 66,29. Sedangkan hasil penilaian sesudah penggunaan bahan ajar dengan konten nilai-nilai kecerdasan emosional berkisar dari 80,35 sampai 85,04. Hasil statistik deskriptif dari penilaian sikap peserta didik sebelum dan sesudah penggunaan bahan ajar dengan konten nilai-nilai kecerdasan emosional diperlihatkan oleh Tabel 2.

Tabel 2. Deskripsi Data Sikap Peserta Didik

\begin{tabular}{|l|l|c|c|}
\hline $\begin{array}{l}\text { N } \\
\text { o }\end{array}$ & $\begin{array}{l}\text { Statistik } \\
\text { Deskriptif }\end{array}$ & Sebelum & Sesudah \\
\hline 1. & Rata-rata & 65,65 & 83,21 \\
\hline 2. & Standar deviasi & 9,17 & 6,90 \\
\hline 3. & Varians & 84,25 & 47,61 \\
\hline 4. & Nilai terendah & 42,00 & 66,25 \\
\hline 5. & Nilai tertinggi & 78,75 & 95,00 \\
\hline 6. & Median & 66,87 & 85,00 \\
\hline 7. & Modus & 73,75 & 88,75 \\
\hline 8. & Rentangan nilai & 36,75 & 28,75 \\
\hline
\end{tabular}

Data pada Tabel 2 memperlihatkan terjadi peningkatan nilai sikap peserta didik antara sebelum dan sesudah penggunaan bahan ajar dengan konten nilai-nilai kecerdasan emosional. Hasil penilaian sebelum penggunaan bahan ajar dengan konten nilai-nilai kecerdasan emosional berkisar antara 58,70 sampai 66,29. Hasil penilaian sesudah penggunaan bahan ajar dengan konten nilai-nilai kecerdasan emosional berkisar antara 80,35 sampai 85,04 . 
Analisis perbandingan berkorelasi juga dilakukan untuk mengetahui signifikansi per bedaan nilai sikap dari peserta didik sebelum dan sesudah penggunaan bahan ajar dengan konten nilai-nilai kecerdasan emosional. Dari perhitungan yang dilakukan menggunakan persamaan koefisien korelasi product moment diperoleh nilai koefisien korelasi sebesar 0,0041.

Berdasarkan perhitungan yang dilakukan menggunakan persamaan t-test korelasi didapat kan t-hitung sebesar -12,02. Nilai derajat kebebasannya (dk) adalah 27. Dari hasil $\mathrm{dk}=27$ dan harga kritik " $\mathrm{t}$ " pada taraf signifikan 5\% diperoleh nilai t-tabel sebesar 1,70. Nilai t-hitung yang didapat dari persamaan t-test korelasi bernilai negatif, jadi untuk menguji hipotesis ini dilakukan uji pihak kiri. Harga t-tabel menjadi 1,70. Nilai t-hitung yang didapatkan lebih kecil dari t-tabel.

Nilai sikap peserta didik sebelum dan sesudah penggunaan bahan ajar dengan konten nilai-nilai kecerdasan emosional menunjukkan perbedaan yang berarti dari uji statistik. Per bedaan yang terjadi menunjukkan adanya pengaruh yang berarti penggunaan bahan ajar dalam pembelajaran fisika. Oleh karena itu, penggunaan bahan ajar dengan konten nilai-nilai kecerdasan emosional adalah efektif dalam pendekatan saintifik untuk meningkatkan kompetensi sikap peserta didik.

Ada tiga hasil yang diperoleh dari penelitian pengembangan konten nilai-nilai kecerdasan emosional dalam materi fisika pada bahan ajar. Hasil pertama yaitu bahan ajar dengan konten nilai-nilai kecerdasan emosional berada pada kriteria validitas sangat tinggi dengan nilai 85,83 , sehingga layak digunakan dalam pembelajaran fisika. Bahan ajar dengan konten nilai-nilai-nilai kecerdasan emosional dibuat sesuai dengan unsur-unsur penyusunan dari sebuah bahan ajar. Sebuah produk akan valid, salah satunya jika produk tersebut dibuat sesuai dengan unsur-unsur yang terdapat dalam acuan. Menurut Depdiknas (2008), sebuah bahan ajar yang baik harus mencakup petunjuk belajar, kompetensi yang akan dicapai, isi materi pembelajaran, informasi pendukung, latihan, lembar kerja, evaluasi, dan respon terhadap hasil evaluasi.

Hasil kedua, bahan ajar dengan konten nilai-nilai kecerdasan emosional berada pada kategori kepraktisan sangat tinggi menurut guru dan peserta didik dengan nilai masing-masing 88,10 dan 82,00 . Bahan ajar dengan konten nilai- nilai kecerdasan emosional dapat diguna kan peserta didik saat belajar mandiri dan dapat memudahkan peserta didik dalam memahami materi pembelajaran. Panduan pengembangan bahan ajar yang dikeluarkan depdiknas (2008), sebuah produk akan praktis jika dapat ber manfaat dalam pembelajaran. Hasil uji kepraktis an sesuai dengan manfaat bahan ajar bagi peserta didik yaitu peserta didik akan mendapat kan lebih banyak kesempatan untuk belajar mandiri dan peserta didik akan lebih mudah untuk mempelajari kompetensi yang harus di kuasainya.

Hasil ketiga, bahan ajar fisika dengan konten nilai-nilai kecerdasan emosional pada kompetensi pengetahuan adalah efektif diguna kan dalam pembelajaran fisika. Hal ini terlihat dari hasil tes pengetahuan peserta didik yang didapatkan melalui hasil prestes dan postes. Berdasarkan data deskriptif dari hasil pretes dan postes yang telah dilakukan menunjukkan bahwa terjadi peningkatan nilai pengetahuan peserta didik sebelum dan sesudah mengguna kan bahan ajar dengan konten nilai-nilai kecerdasan emosional. Hasil ini sesuai dengan ungkapan Sugiyono (2012) yaitu peningkatan nilai menunjukkan pengaruh yang berarti. Sistem kerja baru akan efektif jika nilai setelah treatment lebih kecil dari pada nilai sebelum treatment.

Hasil efektivitas dari bahan ajar fisika pada penilaian sikap adalah bahan ajar dengan konten nilai-nilai kecerdasan emosional juga efektif digunakan dalam pembelajaran untuk meningkatkan kompetensi sikap peserta didik. Setelah dilakukan analisis data, terlihat bahwa terjadi peningkatan nilai sikap peserta didik antara sebelum dan sesudah pemakaian bahan ajar dengan konten kecerdasan emosional. Peningkatan ini menunjukkan adanya pengaruh yang berarti penggunaan bahan ajar. Sistem kerja baru akan efektif jika nilai setelah treatment lebih kecil daripada nilai sebelum treatment (Sugiyono, 2012)

Hasil analisis terhadap data penelitian yang telah dilakukan merekomendasikan bahwa bahan ajar dengan konten nilai-nilai kecerdasan emosional dapat digunakan peserta didik sebagai sumber belajar dalam pembelajaran fisika. Selain itu, bahan ajar dengan konten nilai-nilai kecerdasan emosional dapat juga digunakan oleh guru untuk mengarahkan ke giatan peserta didik dalam pembelajaran fisika di kelas. Reko mendasi ini didasarkan pada pengaruh yang berarti dari penggunaan bahan ajar dengan 
konten nilai-nilai kecerdasan emosional untuk meningkatkan kemampuan peserta didik pada kompetensi pengetahuan dan sikap.

Selama melakukan penelitian ditemukan berbagai kendala karena keterbatasan dari pe laksanaan. Ada dua keterbatasan dari penelitian ini yaitu: Pertama, kesulitan dalam mengembang kan konten nilai-nilai kecerdasan emosional yang relevan untuk setiap konsep-konsep fisika. Penelitian lanjutan diperlukan untuk menambah lagi konten nilai-nilai kecerdasan emosional yang relevan untuk semua konsep-konsep fisika; Kedua, tahapan uji lapangan yang dilakukan belum dampai pada uji lapangan operasional untuk melihat dampak penggunaan produk dalam pembelajaran di berbagai sekolah.

\section{KESIMPULAN}

Berdasarkan penelitian yang dilakukan ada dua kesimpulan yang dapat diambil. Kesimpulan pertama yaitu penggunaan bahan ajar dengan konten nilai-nilai kecerdasan emosional adalah praktis menurut guru dan peserta didik dengan kriteria sangat tinggi berdasarkan komponen penilaian kemudahan penggunaan, manfaat, kemenarikan, dan kejelas an. Kesimpulan kedua yaitu penggunaan bahan ajar dengan konten nilainilai kecerdasan emosional adalah efektif dalam pembelajaran untuk meningkatkan kompetensi pengetahuan dan sikap peserta didik.

\section{DAFTAR PUSTAKA}

Depdiknas. 2008. Panduan Pengembangan Bahan Ajar. Jakarta: Direktorat Pembinaan Sekolah Menengah Atas.

Gardner, Howard. 1993. Multiple Intelligences: The Theory in Practice A Reader. New York: Basic Books.

Goleman, D. 1999. Kecerdasan Emosional. Jakarta: Gramedia Pustaka Utama.

Goleman, D. 2001. Kecerdasan Emosional untuk Mencapai Puncak Prestasi. Jakarta: Gramedia.

Kaimuddin. 2014. Implementasi Pendidikan Karakter Dalam Kurikulum 2013. Dinamika Ilmu (Journal of Education), Vol.14. No1, Juni 2014. Hlm. 47-64.

Kamus, Zulhendri. 2015. Validitas Pengembangan Nilai-Nilai Sosial Dalam Materi Fisika Kelas X SMA Pada Bahan Ajar Bermuatan Kecerdasan Komprehensif. Jurnal Eksakta Vol. 2. Tahun XVI, Juli 2015. Universitas Negeri Padang.
Kamus, Zulhendri., Asrizal. 2016. Implementasi Buku Teks Fisika Bermuatan Kecerdasan Komprehensif Pada Pembelajaran Peserta Didik Kelas X SMA Kota Padang Menggunakan Pendekatan Saintifik. Jurnal Eksakta Vol. 2. Tahun XVII, Juli 2016. Hlm. 44-49. Universitas Negeri Padang.

Kemdikbud. 2017. Panduan Implementasi Kecakapan Abad 21 Kurikulum 2013 di Sekolah Menengah Atas, Dirjen Pendidikan dasar dan Menengah: Jakarta.

Masaong, A. K. 2011. Kepemimpinan Berbasis Multipe Intelligence (Sinergi Kecerdasan Intelektual, Emosional, dan Spiritual Untuk Meraih Kesuksesan yang Gemilang). Bandung: Alfabeta.

Musfah. 2012. Membumikan Pendidikan Holistik, dalam Buku; Pendidikan Holistik (Pendekatan Lintas Perspektif). Kencana, Prenada Media Group. Jakarta.

Permendikbud Nomor 24 tahun 2016 tentang Kompetensi Inti dan Kompetensi Dasar Pelajaran pada Kurikulum 2013 pada Pendidikan Dasar dan Pendidikan Menengah. Jakarta: Kemendikbud.

Ridwan. 2010. Belajar Mudah Penelitian untuk Guru, Karyawan, dan Peneliti Pemula. Bandung: Alfabeta.

Sugiyono. 2012. Metode Penelitian Kuantitatif, Kualitatif, dan $R \& D$. Bandung: Alfabeta.

Sugiyono. 2012. Statistika untuk Penelitian. Bandung: Alfabeta.

Sugiyono. 2016. Metode Penelitian dan Pengembangan (Research and Development). Bandung: Alfabeta.

Syam, J., Asrizal., dan Kamus, Zulhendri. 2017. Pengaruh Buku Ajar Bermuatan Kecerdasan Komprehensif dalam Model Pembelajaran Berbasis Masalah terhadap Kompetensi Fisika Peserta Didik Kelas X SMAN 9 Padang. Jurnal Pillar of Physics Education. Vol. 9. Hlm. 73-80.

Uno, H. B. 2006. Orientasi Baru dalam Psikologi Pembelajaran. Jakarta: Bumi Aksara. 